\title{
Custom and Modern Constructions of Sharía: Transnational Juristic Discussions on the Status of 'Urf
}

\author{
Ayman Shabana \\ Georgetown University in Qatar \\ as2432@georgetown.edu
}

\begin{abstract}
This paper examines modern juristic discussions on the concept of custom in light of the proceedings of the fifth session of the International Islamic Fiqh Academy, which was held in 1988. It shows the extent to which these discussions not only address the role of custom in the derivation of Islamic law and its place in the Islamic legal tradition, but also reflect the impact of modern positive legislations on modern conceptualizations of Sharia and how it has been constructed in the wake of the modern legal reform movement. In particular, the framing of custom in some civil codes as an independent legal source marked a significant development and created tension between Sharîa and modern legal codes. This perceived tension has, in turn, inspired efforts to reaffirm the primacy of Sharĩa and demands for its implementation. While these discussions demonstrate how Muslim scholars situate Sharîa within national legal structures, they also show the role of juristic councils, such as the International Islamic Fiqh Academy, in the development of a transnational juristic discourse that transcends the boundaries of the nation state.
\end{abstract}

An earlier draft of this paper was presented at the conference "Uses of the Past in Islamic Law," which was organized by the Institute of Arabic and Islamic Studies at the University of Exeter (27-29 September 2018). I would like to thank the organizers of this conference for giving me the opportunity to present that draft. I would like also to thank the anonymous reviewers of this journal for their constructive criticism and helpful comments, which have significantly improved this final version. I am grateful to Mutaz al-Khatib for inviting me to contribute to this special issue. Research for this project was supported by a Faculty Research Grant from Georgetown University in Qatar. This publication was made possible by NPRP grant \# NPRP8-1478-6-053 from the Qatar National Research Fund (a member of Qatar Foundation). The statements made herein are solely the responsibility of the author. 


\section{Keywords}

civil law - codification - custom - implementation of Sharīa $a$ - International Islamic Fiqh Academy - juristic councils - legal codes - legal reform - legislation - nation state - positive law - secularity

The relationship between law and custom constitutes one of the most important yet uneasy jurisprudential questions within any established legal tradition. Part of the difficulty surrounding this question lies in the fact that it has at least two main dimensions: philosophical and historical. At the philosophical level, the very definition of law is sometimes rooted in a particular conceptualization of custom as an expression of accepted communal values and practices. In this case the legal system has to clarify the parameters that govern the recognition of certain customs, and thereby distinguishing legally binding customs from other common yet non-binding ones. At the historical level, the emergence and development of law is often traced to a certain pre-law stage of social development, during which custom is usually perceived as the existing applied law. This association between custom and the pre-law phase explains the occasional perception of custom, at least from a strict positivist view, as belonging to premodern, primitive, undisciplined, or irrational periods of legal thought and practice. This dichotomy, however, in the evaluation of the legal role and function of custom between the pre-modern and the modern is neither absolute nor deterministic. At least in the opinion of some legal thinkers, as much as custom was important for the emergence and development of the notion of law itself, it remains as important for the proper functioning of law in the modern period as well (Perreau-Saussine and Murphy 2007, 1-10). Still, from a broader perspective, the notion of custom is important for understanding legal change and the extent to which it is always governed by rational means and causes. The relationship between law and society is quite complex and legal systems do not always respond swiftly to social pressure for change. In fact, law has the tendency to lag behind immediate social needs or demands for legal reform. As much as custom can be one of the means to enable law to accommodate social needs, it can also explain the survival of certain rules when the legal system, through the power of inertia, fails to (or chooses not to) change or amend them (Watson 2001, 1-11).

In the Islamic tradition the nexus between Sharîa, as the underlying foundation of the dominant legal framework, and custom stirred several debates within legal theory, involving issues such as: sources (mașādir); rulings (ahkām); interpretation and legal derivation (istinbāt $)$, and application, 
particularly in novel cases requiring independent legal reasoning (ijtihād) (Shabana 2018). Two main questions, however, have been particularly significant. The first has to do with the eligibility of custom to serve as a legal source in Islamic law. Since Sharîa is believed to be of divine origin, custom, as a source of law, had to be relegated to a secondary or subsidiary status. In other words, custom maybe recognized as a legal source but within a hierarchy of legal sources within which it had to be placed only after the primary scriptural sources. The second concerns the balance that any functioning legal system has to maintain between the normative character and identity of this system, which assumes a certain degree of stability or even fixity of legal norms, on the one hand, and the practical demands for change, arising from social needs and other types of contextual considerations, on the other. The conditions that Muslim jurists stipulated for the integration of custom reveal their concern to maintain the balance between various competing considerations for the normativity and flexibility of Islamic law. The classical Islamic legal corpus is replete with scattered references to the role of custom in the development of Islamic law, permeating the main types of legal genres such as legal theory (ușūl al-figh), substantive law (furū), and legal implementation (court decisions and the fatwa literature). Subsequently, custom has also featured prominently in other later genres such as legal maxims (qawā'id); similarities and distinctions (ashbāh wa-furūq); as well as legal objectives (maqūșid).

But, questions pertaining to the role and function of custom in Islamic law are not limited to classical legal texts reflecting the primacy of Sharía as the main source of legal norms within a Muslim polity. They remain as important and relevant in the modern period also, although in a completely changed legal landscape. At a broader level, the concept of custom is critical for the development of a more nuanced understanding of both tradition and modernity. Instead of the usual Eurocentric conceptualization of tradition, as the embodiment of archaic practices which should give way to the all-powerful forces of modernity, some researchers point out the possibility of multiple forms of modernity on the basis of combinations between different types of traditions with specific forces of change, which may, in turn, give birth to distinctive modern societies (Salvatore 2009, 6). Within the Islamic civilization, the concept of custom can offer valuable insights not only on how the Islamic tradition, particularly in the legal sphere, has developed in the past, but also how it has continued to be interpreted, imagined, and constructed to meet the needs of Muslim communities in different social and cultural settings.

This article focuses on modern juristic discourses concerning the authority of custom in Islamic law. It examines part of the proceedings of the fifth session of the International Islamic Fiqh Academy (IIFA, held in Kuwait in 
December, 1988), which addresses the status and role of custom in Islamic law. The proceedings reveal not only the role of custom in the derivation of Islamic legal rules in an abstract or theoretical way but also, more generally, how much custom-related discussions have shaped modern constructions of Sharía. In other words, they reveal how Sharîa was perceived by the participants and how, in their contributions on custom, they sought to assert the status of Sharía and emphasize its viability to (re)assume its rightful position, following the introduction of secular law and civil codes. The place of Sharita in the modern period has been the subject of continued and multi-faceted debates on a wide range of social, legal, and political issues. Most of these issues can be traced to important developments that took place in the Muslim world over the past two hundred years, particularly in response to two main events: the demise of the caliphate system and the subsequent rise of the nation state; and the legal reform and codification movement (Hallaq 2009, 357-70). Although in most Muslim-majority countries, the modern codification movement dates back to the 19th century, these proceedings show that the controversies that surrounded their introduction, especially those concerning the impact on Shari $a$, did not die out. These proceedings are important because they show how Muslim jurists grappled with these issues in their efforts to reconcile the classical legal tradition and modern social and political realities. Moreover, the issues that the proceedings deal with remain for the most part relevant, as the recent events of the Arab Spring have clearly shown. For example, in countries such as Tunisia and Egypt, one of the ensuing debates that started soon after the first wave of popular uprisings in 2011 had to deal with constitutional reform. The meaning of the civil state (al-dawla al-madaniyya) and the extent to which it can accommodate Sharía regulations was one of the central questions in this debate (Grote et al. 2016). From an organizational perspective, the proceedings highlight the role of modern transnational juristic institutions not only in the examination of particular legal-moral questions but also in setting the agenda for juristic deliberations by identifying important questions and topics of the highest priority. ${ }^{1}$ Still, from a historical perspective, the proceedings demonstrate and confirm the consolidation of custom as a prominent topic in modern juristic discourses. By contrast, pre-modern jurists often dealt with custom as a subsidiary topic in connection with certain issues either in legal theory or in substantive law (Shabana 2010, 1-2). The singling

1 Studies investigating the place of Sharîa in the modern period, including areas of interface with positive legislation, tend to concentrate on the context of the nation state, either within a Muslim-majority (Skovgaard-Petersen 1997; Lombardi 2006; Agrama 2012) or minority context (Jackson 2015). 
out of custom as a main theme for discussion reveals added emphasis on the potentials of custom as an important tool for legal reform and renewal.

This article seeks to demonstrate the importance of these proceedings for modern constructions of Shari $a$ by highlighting two main points. The first is the relationship between Sharía and positive legal systems in Muslim-majority nation states, which, according to these proceedings, has been shaped by a significant degree of rivalry and contestation. The second is the nature and scope of Sharía in terms of: its claim for comprehensiveness, the efforts to ensure its adaptability, and also demands for its implementation. The article shows that these discussions sought to demonstrate how much custom can enhance the position of Sharía not only to meet demands for its implementation in general but also, as numerous other IIFA sessions illustrate, to help address new and unprecedented questions on a wide range of issues. Before turning to these two main points, the paper will begin with a general overview of these proceedings and their contents.

\section{Solicited Papers on Custom: Structure, Approach, and Main Points}

The International Islamic Fiqh Academy (IIFA) is one of the main entities affiliated with the Organization of Islamic Cooperation (formerly Organization of Islamic Conference). It held its inaugural conference in Mecca in June 1983 on the basis of a resolution that was issued eighteen months earlier during the OIC Islamic summit conference, which was held in Mecca in January 1981. According to this resolution, the IIFA was established with the aim of promoting Islamic unity and solidarity. By addressing new and emerging issues, it was meant to serve as a forum to facilitate deliberations among Muslim jurists and experts on modern problems, particularly those that require independent legal reasoning or ijtihād (Majma' al-Fiqh al-Islāmī 1986, 43). The IIFA holds regular meetings to discuss pre-planned topics, for which contributions from its members as well as prominent subject-matter experts are solicited and distributed in advance among the participants in preparation for collective discussions prior to, and in preparation for, the resolutions or recommendations that are issued at the conclusion of the scheduled meetings. Due to the importance of the issue of custom, it was included on the agenda of IIFA's fifth conference, which was held in Kuwait on December 10-15, 1988.

The submitted contributions comprise eleven papers of varying length and depth by a diverse group of jurists and legal experts from across the Muslim world including: Khalīl Muhyī al-Dīn al-Mays (Lebanon), Kamāl al-Dīn Ju'ayyiṭ (Tunisia), Ibrāhīm Fāḍil al-Dabw (Iraq), Muhammad 'Ațā al-Sayyid Sayyid 
Aḥmad (Sudan), 'Umar Sulaymān al-Ashqar (Jordan), Muḥammad Jabr alAlfĩ (Egypt), İbrahim Kafi Dönmez (Turkey), Mạmmūd Shammām (Tunisia), Muhammad 'Alī Taskhīrī (Iran), Boubacar Doukoure (Burkina Faso), and Muhammad 'Abduh 'Umar (Yemen). In terms of general approach and methodology, these eleven contributions include two main orientations: traditional and comparative. The traditional orientation follows classical juristic formats and concentrates on various aspects associated with the development and treatment of the concept of custom in the Islamic legal tradition. The comparative dimension covers, in addition to classical juristic discussions, examinations of how custom has been discussed by (positive) legal scholars and how it was utilized by modern legal actors in the process of developing legal codes during the colonial period or in the emerging Muslim-majority nation states in the post-colonial era. The following two sections survey the broad lines that these two orientations entail.

\section{The Traditional Orientation}

Several contributions have concentrated almost exclusively on how custom was utilized by classical jurists and how it featured in pre-modern legal texts. These contributions trace relevant discussions in the juristic tradition by highlighting significant debates in legal theory on questions such as the definition, classifications, authority, and conditions of a normative custom or by tracing practical examples in substantive law involving juristic implementation of the concept of custom. From this perspective, the relationship between Sharía and custom can be traced to the formative period of Islam and the history of this relationship should be placed within the wider pre-Islamic context by examining how the Prophet regulated preceding Arabian practices. Islamic regulation of such practices ranged from condemnation and prohibition as is the case with certain types of commercial transactions involving uncertainty and deceit to conditional approval and reformulation as is the case with institutions governing marriage, divorce, retaliation, and slavery. After the death of the Prophet the companions, and subsequent Muslim scholars, assumed the same attitude towards customary practices in other regions outside Arabia, whereby customs deemed compatible with Islam were approved while those deemed incompatible were denounced and considered illegitimate (al-Mays 1988, 2928-9; al-Ashqar 1988, 3224-5; Dönmez 1988, 3307-8).

\section{Definition and Legitimacy of Custom}

The legal concept of custom is associated mainly with the two terms 'urf and 'a da. Its definition is often traced to the linguistic roots of these two terms as well as the technical meaning they acquired in the juristic idiom. Etymologically, 
the term 'Urf is connected with two roots that denote: succession and the following of one thing after the other; and stillness and serenity. While the first indicates repetition and recurrence, the second indicates the feeling associated with knowledge, acquaintance and familiarity (Ibn Fāris 1979, 4:281). One of the famous technical definitions of 'urf denotes what has been established among people and instilled in their hearts (istaqarra fïal-nufüs) through the testimony of reason and deemed acceptable to natural dispositions (al-Jurjānī 2009, 152). ${ }^{2}$

While some jurists use these two terms interchangeably, other jurists distinguish between them on the grounds of scope or legal force (Ju'ayyit 1988, 3000, 3115; al-Ashqar 1988, 3218). For example, some scholars use 'áda for actions and 'urf for linguistic conventions; others use 'áda only for actions and 'urf for either actions or linguistic expressions; and still others use 'āda for an individual custom and urf for a collective one. In addition to the two terms 'urf and ' $\bar{a} d a$, custom has also been associated with other juristic terms such as 'amal (practice) and $\ddot{j} m \bar{a}^{c}$ (consensus). The former has been used in the Mālikī school originally to denote the established practice of the people of Madinah. While some scholars equated 'urf and 'amal, others distinguished them by reserving the term 'amal to a practice that is backed by an existing legal opinion within the school. With regard to juristic consensus, although some scholars argue that $u r f$ represents a form of $\ddot{j} m \bar{a}^{c}$ since it stands for the agreement of some or the majority of the Muslim community, several distinctions are made between them: $\ddot{j} m \bar{a}^{c}$ stands for the agreement of qualified and competent jurists and 'urf refers to the agreement of people in general; $\ddot{j} m \bar{a}^{c}$ does not require recurrence but it is considered effective once it is established while 'urf has to be recurrent; and $i j m \bar{a}^{c}$ has to be founded on scriptural text or an analogy thereof but 'urf does not (al-Alfì 1988, 3264-8; Doukoure 1988, 3412).

The legitimacy of custom is grounded in scriptural references in the foundational sources, particularly ones that include the two terms 'urf and ma'rüf. The term ma'rüf literally stands for what is known or what is commendable and it is often conjoined with its opposite munkar in the scriptural sources. It is reiterated throughout the Qurān to regulate various social aspects of the nascent Muslim community as is the case with 2:233; 4:19; and 65:7, which relegate exact determination of appropriate amounts of expenditure to common custom. The term 'urfitself, on the other hand, occurs twice. The first (7:199),

2 This definition is attributed to the Ḥanafi jurist Ḥāfiz al-Dīn 'Abd Allāh ibn Ahmad al-Nasafĩ (d. 710/1310) in his book al-Mustasfā (Ibn 'Ābidīn n.d., 2:112; Abū Sunna 2004, 28), although it is sometimes traced by mistake to a book by Abū Ḥāmid al-Ghazālī (d. 505/1111) with a similar title (Dönmez 1988, 3309; Shammām 1988, 3374). al-Nasafì's definition, however, includes "good natural dispositions" (al-țibā'al-salìma) while al-Jurjānī's definition makes reference to "natural dispositions" $(\underline{t} i b \bar{a})$ without any qualification. 
which is cited more frequently, is considered one of the main scriptural references to custom in the Qurann in addition to being one of the fundamental Islamic moral principles. In the exegetical tradition, the term 'urf in this verse has been subject to multiple interpretations including: general moral principles, established rules of Shari $a$, and commonly accepted customs. ${ }^{3}$ The second (77:1) relates more to the linguistic meaning of the term, and is not considered indicative of the technical juristic connotation of custom (Ju'ayyit 1988, 2985-6; Dönmez 1988, 3339-41). Apart from explicit references to 'urf, scholars also point out implied or implicit references. For example, some have referred to (Q 22:78, "And He did not impose any hardship on you because of religion") to argue that overlooking people's common customs would ultimately result in hardship, which would go against this Qurānic injunction (Dönmez 1988, 3347; Doukoure 1988, 3416; 'Umar 1988, 3426).

Within the Prophetic Sunna, one of the famous reports often cited to establish the legitimacy of custom indicates that: "what Muslims deem to be good is also good in the sight of God and what they deem bad is also bad in the sight of God." This report is included in the Musnad of Ahmad ibn Hanbal and is traced to the companion Ibn Mas' $\bar{u} d$ rather than the Prophet himself. Apart from this report, the Sunna of the Prophet is replete with explicit and implied references to custom, particularly in traditions involving the incorporation of common custom in the wider domain of transactions (Ju'ayyit 1988, 3001-7).

Although the legitimacy of 'urf is usually predicated on textual foundations through explicit or implicit references in the scriptural sources, some scholars also investigated the legitimacy of custom on the basis of rational-theological arguments. In other words, to what extent can reason be used to make a judgement on the moral status of a certain custom and its appropriateness, either independently or together with Sharîa? This question is closely tied to the classical debate on moral epistemology in the Islamic normative tradition, which is known as the good (husn) and the bad (qubhh). In general, theologians agree that reason can distinguish what is good and what is bad. The disagreement, however, lies in the means through which divine will can be known and

3 On the various views on the term 'urf in this verse in the exegetical tradition, see al-Jīdī 1982, 53-6. In his commentary on this verse in Tafsìr al-Manār, Rashīd Riḍa (d. 1935) disputes the view of some commentators that the term 'urf here is limited to established rules and principles of Sharīa. According to Riḍa, the generic connotation of the term includes what is known and established in Sharía, common customs, and interpersonal transactions. With regard to the term ma'rüf, he traces the development in its usage from the Meccan period to the later Medinan period. While it was used during the initial Meccan period to denote general commendable values and moral principles, it was used subsequently in the Medinan period in connection with specific legal rules (Riḍā n.d., 9:456-8). 
whether such knowledge can be achieved independently of revelation. Three main views are often distinguished. The first is the view of the rationalists, represented by the Mu'tazili school of theology, according to which, reason can reach an independent judgement of what the Sharîa requires or expects. Since Sharía rules are meant ultimately to achieve people's benefits, such a judgment can be made on the basis of evaluating ensuing benefits or harms of a given action. The Asha'rī view, on the other hand, is that Sharîa rules cannot be known independently by reason but it has to be based on revelation. ${ }^{4}$ The Mātūrīdī school developed an intermediary position according to which, Sharía rules can be known rationally but can only be established by revelation. What is important to note here is that these theological views on the foundation of moral judgement had a role to play in the juristic views concerning custom and also in the interpretation of related scriptural sources (al-Alfi 1988, 3277-9).

\section{Classifications of Custom}

Over the course of the Islamic legal tradition, several classifications have been devised to distinguish different types of custom on the basis of considerations such as its nature, scope, usage, and authority. To begin with and in terms of its conformity with Sharîa, custom is divided into two main types: valid or sanctioned and invalid or prohibited. The former does not contravene any explicit Sharîa $a$-based stipulation, and is, therefore, considered acceptable. The latter stands for customs that go against a Sharîa-based injunction, and it is therefore condemned and considered unacceptable. In terms of its nature, custom is divided into two main types: verbal or linguistic ( qawlī) and practical ('amalī). The first includes conventional meanings that are commonly associated with certain terms such as the term dirham, which could be used to refer to any currency bearing this name. When the term is used without any further qualification it is taken to mean the common currency in a specific region. Linguistic customs can be singular as is the case with dirham or compound as is the case with idiomatic expressions. Conventional terms and expressions are also distinguished from Sharīa-specific expressions as is the case with

4 The famous Ashárī theologian Sacd al-Dīn al-Taftāzānī (d. 793/1390) notes that according to the Mu'tazilī view, Sharīa positive and negative commands (amr wa-nahy) are consequences of the moral judgement (whether good or bad). According to the Asha'rī view, on the other hand, the positive and negative commands of Sharita are the underlying justification for moral judgement. In other words, while, according to the Asha'rī view, Sharīa establishes moral-legal judgements, according to the Mu'tazilī view, Sharî̃a reveals or confirms such judgements (al-Taftāzānī 1998, 4:238). For further details on the theological underpinnings of juristic discourses on custom, see Shabana 2010, 59-70. For further analysis on the Mu'tazilì and Ash'rī views see Vasalou 2008 and Shihadeh 2006. 
terms such as prayer (șalät). While the generic meaning of the term covers any form of prayer, the Sharita-specific usage of the term refers exclusively to the Islamic meaning and form of prayer. Practical customs stand for common practices, which may cover: habitual practices involving ordinary or regular activities such as eating certain types of meat in particular regions; or habitual practices involving commercial transactions such as those linked to the sale or lease of certain items. In terms of scope, custom is divided into general ('âmm) and specific (khāsss). The former covers common universal customs among all Muslims, either in the past or in the present as is the case with the use of certain terms such as talāq (divorce), which is used for the termination of the marital relationship. Specific customs stand for customary practices or conventions within certain regions, professions, religious communities, or ethnic groups. (al-Mays 1988, 2930-2; al-Dabw 1988, 3178; Sayyid Ahmmad 1988, 3203-4).

\section{Usage, Scope of Application, and Conditions}

In terms of usage, custom has been used in several ways including the following: as a proof (dalīl), as a standard in legal application, or as an implied or supporting (circumstantial) evidence. The use of custom as a proof is usually highlighted in the domain of commercial transactions in connection with certain types of agreements that seem to violate a general principle. Examples include the contract of manufacture (istișn $\bar{a}^{c}$ ), which goes against the ban on selling non-existent items or endowment (waqf) of movable items (including cash), according to some jurists, which goes against the restriction of endowment to immovable property.

Another important usage of custom occurs within the domain of legal application, particularly in the case of unqualified rules. Custom is used here as a measure to provide necessary contextual information to suit the particular incident in question. Examples to highlight this usage of custom are numerous and they relate to the different sections of the legal corpus ranging from rituals to penal rules. One of the important examples in the area of penal law is the appropriate form of discretionary punishment $(t a z i r)$, which is left to the evaluation of the judge in light of the specific circumstances of the case. One of the important legal maxims in this regard is the one indicating that any general or absolute rule that does not include any form of specification or qualification either in Sharîa or in language, should be properly qualified according to custom (al-Mays 1988, 2935; Ju'ayyiṭ 1988, 3043-58; al-Dabw 1988, 3196-9; Taskhīrī $1988,3406) .{ }^{5}$ The use of custom as a type of implied evidence includes custom-

5 In general, custom often features prominently in the legal maxims genre as one of the main and comprehensive maxims, which permeate all the sections of the legal corpus (al-Suyūṭī 2004, 221-238; Ibn Nujaym n.d., 101-112; Ḥaydar 2010, 40-8). 
ary implications denoting permission, refusal, or agreement. It also includes conventional meanings associated with certain terms or linguistic expressions (Ju'ayyit 1988, 3102). In addition to these uses, some authors pointed out other ways in which custom was used in the legal tradition. For example, al-Mays notes three examples: use of custom to give preference to certain legal opinions over others, if deemed more suitable to dominant customs; use of custom to determine the monetary value of certain items; and use of custom to justify the change of certain rules (al-Mays 1988, 2937). These multiple uses of custom are highlighted to denote both the ubiquity of custom, and the extent to which it was deemed authoritative (al-Mays 1988, 2951).

In order for a custom to be recognized, the jurists stipulated several conditions that had to be met. First, custom had to be recurrent and dominant, as was the case with the identification of common currencies in the absence of specific indication. Second, it had to be general as was the case with customs that indicated a collective general need such as the need for the contract of manufacture (istișna $\bar{a}^{c}$ ). Third, it had not to be conflicting with established Sharia rules, as was the case with a custom that violated the ban on incest. Fourth, it had to be in existence at the time of the agreement or contract in question and had not to be conflicting with an explicit indication therein. Fifth, it had to be commonly recognized as binding, as was the case with the exchange of gifts in certain occasions (al-Mays 1988, 2962-4; Ju'ayyit 1988, 3038; al-Dabw 1988, 3190-2; al-Ashqar 1988, 3238-9; Shammām 1988, 3381).

\section{The Comparative Orientation}

Some contributions combined traditional juristic discourses on custom with modern legal discussions in the realm of secular legislation and jurisprudence. The comparative dimension in these contributions is highlighted in connection with several points such as the definition or conditions of a valid custom. For example, some authors, in their survey of the various juristic definitions of custom as well as the distinction between 'urf and ' $\bar{a} d a$, note that (positive) legal scholars distinguish between 'urf, which is considered binding by itself and $\bar{a} d a$, which requires further confirmation and ascertainment. This distinction is grounded in an added formal pillar (ma'nawì) of 'urf that signifies the general acceptance and recognition of 'urf, in addition to the material pillar that signifies the existence and recurrence of a certain practice, which is shared by both 'urfand 'āda. (Ju'ayyiṭ 1988, 3000; Dönmez 1988, 3304; al-Ashqar $1988,3215)$. The conditions of a legally valid custom also have to do with the distinction between 'urf, which is seen as having achieved a significant degree of dominance and recurrence that merit public and official recognition as opposed to 'a $d a$. Some scholars, however, noted that this (positive) legal 
distinction between 'urf and 'a $\bar{d} a$ on the basis of an added formal pillar is elusive as it is not always easy to verify and establish this pillar. This critique is particularly made by authors who support the view of using both 'urf and 'a da as synonyms, and generally emphasize the advantage of the juristic discourse on custom over its secular counterpart (al-Ashqar 1988, 3217-20).

After this overview of the authors' contributions, the following part of the paper concentrates on the two main points mentioned above. These two points were chosen not only because almost all authors addressed them in varying degrees of detail, but also because they were the main focus of the collective discussion among the authors, together with the other participating scholars.

\section{Custom between Sharīa and Positive Legislation}

As noted above, the IIFA proceedings on the status of custom, comprising both the solicited papers and the collective discussion, reveal a general sense of tension between Shari $a$ and positive legislation. With regard to this issue, the main concern that seemed to occupy most participants was the modern relevance of classical discourses on custom and how, in turn, these discourses can contribute to the improvement of the status of Sharía vis-à-vis secular law. The sense of tension between Sharîa and positive legislation is manifested in several points that were highlighted, particularly during the collective discussion. One of these points was the status of custom as a legal source or as a type of proof, particularly in light of the emergence of civil codes throughout Muslimmajority countries in the 19th and 2oth centuries. By elevating the status of custom and broadening its scope, these codes generated controversies on the admissibility of custom and its force, which often involved a comparison of the status of custom under Sharīa and secular law.

In general, custom is not recognized as an independent legal source within the Islamic legal tradition. The main concern that many pre-modern jurists had revolved around was the question of conflict with a specific textual indication and the extent to which such a conflict can be resolved. For example, preIslamic practices that were condemned would not be approved if they were to reemerge. On the other hand, if a custom conflicted with a generic scriptural indication, an exception could be made in case the custom in question is general, as was the case with istișna $\bar{a}^{c}$ (al-Dabw 1988, 3192; Dönmez 1988, 3355). ${ }^{6}$ It was often emphasized that making such an exception through specification

6 The possibility of making exceptions in the case of specific customs, such as those that are common in certain regions, is disputed (Ibn 'Ābidīn n.d., 2:114). 
(takhșiș) would not amount to nullification of a text-based rule. By contrast, specification would entail implementation of both rules at the same time by giving effect to the most appropriate form of application of the text in a manner that reconciles the seeming tension between a general textual indication and an existing common custom (al-Mays 1988, 2938; 'Umar 1988, 3433). Therefore, when used as a type of proof, custom is usually qualified as derivative, subsidiary, or secondary. ${ }^{7}$ In general, there are two main approaches for the incorporation of custom within this Islamic evidentiary framework. On the one hand, some jurists count custom as a type of proof by itself if it satisfies certain conditions. ${ }^{8}$ The second approach, on the other hand, traces custom to another underlying source, which may be consensus, juristic preference, or benefit (al-Alfì 1988, 3274-6; al-Dabw 1988, 3189-90; Taskhīrī 1988, 3407). Some participants traced the disagreement on the legal status of custom to the technical meaning of certain terms such as proof (dalīl), source (mașdar), and other related terms such as essence (așl). For example, the Turkish scholar İbrahim Dönmez notes that custom can be regarded as a source in the sense of being a repository of real life practices but it cannot be regarded as a source in terms of independent authority due to the nature of the Islamic evidentiary structure, which is predicated on revelatory sources (Dönmez 1988, 3357-8, 3458). Similarly, the famous late Iraqi scholar Țāhā Jābir al-'Alwānī (d. 2016) notes that authoritative proofs under Sharîa are the Qurān and the Sunna of the Prophet in addition to juristic consensus, which is closely tied to them. All other so-called proofs are merely signs that the jurists utilize for the understanding of a given social setting in the process of implementing the most appropriate scriptural proof (Majallat 1988, 3459).

This background on the treatment of custom in the Islamic legal tradition explains why most contributors were critical of the prominent role that was given to custom in modern legal codes in the Muslim world. In particular, the Egyptian civil code is criticized and considered deficient mainly for featuring custom prominently as an independent legal source, even before Sharîa itself. The prominent role that custom occupied within the civil codes of Muslim countries is seen as a direct result of the foreign influences that shaped these

7 By definition, proofs (adilla, sing. dalil) are the means through which practical legal rules are derived. They serve as pointers or indicators to God's will on a particular issue and they could be textual or rational (Abou El Fadl 2001, 34). They include the agreed upon scriptural sources of the Qurān and Sunna of the Prophet in addition to juristic consensus (ijmāc) and analogical reasoning (qiyās). They also include a number of contested proofs such as juristic preference (istiḥsān) and public interest (mașlaḥah).

8 In the pre-modern period some jurists referred to custom as a type of proof as is the case with the Mālikī jurist Ibn al-'Arabī (Ibn al-'Arabī 2002, 4:281-2). 
codes. For example, the Tunisian scholar Kamāl al-Dīn Ju'ayyiṭ underscores these foreign influences by quoting a statement by the famous Egyptian lawyer 'Abd al-Razzāq al-Sanhūrī (d. 1971), the lead author of the updated version of the Egyptian civil code of 1949. In this statement al-Sanhūrī describes the French impact on modern civil codification in Egypt as a type of "legal occupation" and calls for gradual liberation of this code to ensure its authenticity and independence (Ju'ayyit 1988, 2983)..$^{9}$ The subsequent Iraqi and Syrian codes are also criticized for following the same model. By contrast, the Jordanian civil code is seen as more consonant with Sharîa for listing custom as a secondary source that comes after the revelatory sources (al-Khayyāt 1977, 7-12).

The example of the new Egyptian civil code of 1949 is quite significant not only due to the important role it played in inspiring similar codes in other Arab countries but also due to the controversy it stirred, particularly, for the purpose of this paper, in view of its framing of custom as an independent legal source. ${ }^{10}$

The notion of legal occupation (ihtilāl) or colonization (isti'mār) is part of the larger notion of intellectual invasion (al-ghazw al-fikrī) or cultural invasion (al-ghazw al-thaqā $\bar{f}$ ), which has often been used to describe the impact of Western modernity on the Muslim world (Mahmūd 2003, 230). On the other hand, some researchers trace the idea of codification to earlier phases of Islamic history, particularly in light of the suggestion that 'Abd Allāh ibn al-Muqaffa' made to the Abbasid Caliph al-Manșur. Although the suggestion was not adopted, it is considered one of the earliest attempts to unify Sharîa rules through codification (Abū Țālib 2006, 255).

10 Civil codification in Egypt started with the development of several codes for the mixed courts in 1875 during the reign of Nūbār Pasha (d. 1899), the prime minister under Khedive Ismā'il (r. 1863-1879). Subsequently, another set of codes were developed in 1883 for the emerging Egyptian courts. These early codes were, for the most part, influenced by foreign, mainly French, codes (al-Sanhūrī 2006, 2:497; Ḥusayn 2001, 1: 41-4). Efforts to revise these initial codes in order to make them more compatible with the Egyptian society started in 1936, when the ministerial cabinet issued a decree on February 27, 1936 to formulate a committee for this purpose. This committee however, was later dissolved on May 26, 1936. Another committee was formed later in the same year on November 20 and it lasted for 18 months. On June 16, 1938 the Ministry of Justice sent a memo to the cabinet explaining how experience showed that formation of large committees is less effective than assigning the task to one or two experts. Once the task is completed, drafts can then be reviewed by experts and also by the general public. The Ministry suggested choosing two experts (one Egyptian and one foreigner) and requested authorization for the Minister of Justice to choose them. The memo was approved on June 21, 1938 and on June 28 the Minister of Justice issued a decree assigning the task to the Egyptian legal scholar 'Abd al-Razzāq al-Sanhūrī (then serving as a judge in the mixed courts) and the French legal scholar Edouard Lambert. This committee completed the task and produced a preliminary draft of the civil code, which was published in 1942 to facilitate distribution and commentaries, particularly from experts in the legal field. Three years later (on March 29, 1945), a committee consisting of four members and led by al-Sanhūrī was formed to revise the draft in light of the comments that were generated during this 
The public debate that surrounded this code from its initial draft in 1942 until its final approval and implementation in 1949-involving not only traditional scholars but also different stakeholders, including lawyers and judges—reveals two main perspectives. ${ }^{11}$ Its supporters, as represented mainly by its lead author 'Abd al-Razzāq al-Sanhūrī, saw it as an opportunity to minimize the influence of foreign, mainly French, law and as an important step to achieve further degrees of independence in the future. Critics, on the other hand, had many reservations on various aspects of this new code (Wizārat al-'Adl 1950, 37; al-Ashqar 2012, 121-48; Shalakany 2001, 227). For example, when the draft code was submitted to the Egyptian Senate in 1946, three main reservations were raised: multiplicity of sources even for single articles; broad scope and degree of detail, which were believed to limit the role of judges; and connection to the preceding code and exiting legal practice, including the extent to which reform can be undertaken by fixing the existing code rather than developing a new one (Wizārat al-'Adl 1950, 1:38-41). The question of the sources was perhaps the most controversial one, both in terms of the inclusion of custom as an independent source and also the relative order that it occupied vis-à-vis the other sources, especially Sharita. As the earlier drafts of the code show, the first article, dealing with the sources of the code, underwent significant changes in the various subsequent drafts. For example, the initial draft listed only three sources: legislation, custom, and principles of natural law and justice. Sharita was added later and listed after custom during the first phase of revision before it was sent to the Parliament (Wizārat al-'Adl 1950, 1:182-190). The discussions that surrounded the ratification of the new civil code show that both the supporters and critics of the code were sympathetic towards the incorporation of Sharía but they had different approaches to achieve this incorporation. For example, critics insisted on explicit indication concerning the role of Sharĩa not just as a general source, but to the extent possible for individual

period. The draft was then sent to the ministerial cabinet (on November 22, 1945) and subsequently to the Parliament, where it remained under review from December 1945 until May 1946. The draft was then sent to the Senate, which decided to forward it to a special internal committee, which was called the Civil Code Committee. The draft remained under review in the Senate for almost two years (from May 27, 1946 until June 28, 1948). After further revisions, it was then sent back to the Parliament for further deliberations. The draft was approved on July 16, 1948 (published in the official gazette on July 29, 1948) with a decree indicating that it should enter into force the following year, as of October 15, 1949 (Wizārat al-'Adl 1950, 1:5-9).

11 It should also be noted that public controversies concerning the place of Sharita and Islam in the public sphere were not limited to the issue of the civil code. Similar controversies have also surrounded the constitutions that were developed during the 2oth century (see, for example, Abū Țālib 2006; Lombardi 2006; Lombardi and Brown 2006). 
articles (Wizārat al-'Adl 1950, 1: 99-101, 115, 160). Some senators even suggested the invitation of senior scholars from al-Azhar to take part in the discussion in the Senate and also to contribute to it in a more substantive way (Wizārat al-Adl 1950, 1:83, 1:115). Al-Sanhūrī, on the other hand, saw the new civil code as an opportunity not only to free Egyptian law from foreign influences but also as a means to modernize Islamic law itself by reintegrating it into the new code and allowing it to interact with modern legal practice in a dynamic way. In defense of his approach against critical remarks from the opposing senators, he did not see a problem in filling gaps with elements from other foreign laws and legal systems (Wizārat al-'Adl 1950, 1: 85-90, 159). Although some articles in the civil code are inspired by and derived from Islamic law, it generally retained the foreign influences that shaped the earlier codes that were developed in the late 19th century. In explaining this state of affairs as well as the order of the sources in the updated civil code of 1949, al-Sanhūrī noted that the authors of the code took into consideration the impact of the earlier codes and the changes that they had introduced. It was felt that the process of harmonizing the code with Sharía should be gradual, because a radical change would cause significant problems (al-Sanhūrī 2006, 2:541). While al-Sanhūrì is usually acknowledged for his command of Sharîa and the premodern juristic works, it is not clear whether and to what extent he involved the traditional scholars while working on the new civil code. When he was asked whether he consulted with the Sharīa scholars, he replied: "we did all we could in this regard. We took all we could from Sharîa while unfailingly maintaining the proper principles of modern codification" (Wizārat al-'Adl 1950, 1: 159). ${ }^{12}$ It was perhaps this ambivalent answer that gave the impression, at least to the 'ulama', that the new civil code placed Sharía in a secondary position relative to legislation and also to custom. ${ }^{13}$ Some scholars even wrote com-

12 (la-qad qumnā bi-kull mā yumkin 'amaluh fì hadhā al-sabīl wa-akhdhnā kull mā yumkin

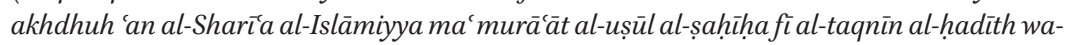
lam nuqașsir fi dhälik).

13 In his biography of his teacher Muhammad 'Abduh (d. 1905), the founder of the famous journal al-Manār Muhammad Rashīd Riḍa discusses the reaction of al-Azhar scholars to modern legal reform and to codification. Riḍa blames the scholars for failing to undertake necessary reform in Islamic law and argues that this failure ultimately led to the substitution of Sharîa by secular law. For example, he notes that Khedive Ismāîl tried, with no success, to convince al-Azhar scholars to develop a compendium of Sharía rules along the lines of modern European codes. He also asked Rifāáa al-Ṭahțāwī to inform the scholars that he (Ismāîl) was facing pressure from the Europeans to adopt French law, if the scholars failed to modernize Islamic law (Riḍā 2012, 1:620-1). Although these efforts did not succeed, it is important to note that not all the scholars stood against this legal modernization movement and that several individual efforts were undertaken to 
parative works to defend Sharîa and prove its precedence to modern French codes (Ḥusayn 2001). ${ }^{14}$

Assessment of the prominent role that al-Sanhūrī played in the development of the civil code, particularly in as far as he was able to bring it closer to Sharita has been contested, mainly due to several conflicting statements by him on this issue. On the one hand, al-Sanhūrī defended the draft code against vehement criticism on the grounds that it gave primacy to legislation and custom over Sharita. In response, he argued that the draft code represented a significant achievement towards the ultimate goal of modernizing Egyptian law while in the process also modernizing Islamic law (al-Sanhūrī 2006, 2:542). More particularly, with regard to the role of custom as an independent legal source in the new civil code, it was argued that custom is not entirely foreign to Sharía because it often involves various aspects of Islamic law as implemented in specific regions (Wizārat al-'Adl 1950, 1:92; Shalakany 2001, 229, 233). On the other hand, al-Sanhūrī was reported, later in his career, to have had second thoughts concerning the Islamic character of the Egyptian civil code (Shalakany 2001, 243). Moreover, in his frequent comparison between the Egyptian and Iraqi civil codes, he often noted their different genealogies. Although he was also the lead author of the Iraqi code, he recognized that the Iraqi code was closer to Sharîa due to its connection with the Ottoman Majalla, which was formulated according to the Ḥanafĩ substantive law (al-Sanhūrī 2006, 2:523-9, 546).15

facilitate the modernization of Islamic law. For example, an attempt was undertaken by sheikh Makhūf ibn Muḥammad al-Badawī al-Minyāwī (d. 1878), who served as a judge in upper Egypt, in response to this proposal by Ismā̄̄il. Shaykh al-Minyāwī undertook a comparative study between the Arabic version of the French civil code and Islamic law, by mainly listing the articles of the French code and commenting on them with relevant rules within the Mālikī school. In this work, al-Minyāwī emphasized the areas of similarities between these two legal systems (al-Minyāwī 2010). Another attempt was undertaken by Muhammad Qadrī Bāshā (d. 1886) who produced several books in which he developed codified versions of Islamic law according to the Hanafĩ school (Qadrī 2007, 2011), following the example of the Ottoman Majalla (Haydar 2010).

14 For example, Sayyid 'Abd Allāh 'Alī Ḥusayn, an Azharī scholar who studied positive law in France, wrote a comprehensive comparative work in which he examined the French civil code with established rules in the Mālikī school. In this work he argues that the influence of Mālikī doctrines on French law are visible. He traces the contact between these two systems to Muslim rule in al-Andalus. The work took about eight years to be completed and it was finished in 1948, when the draft civil code was under discussion. In this work, the author aimed to: prove the originality of Islamic law and its superiority over French law; and to call for revising the draft civil code to make it more consonant with Sharîa. In the introduction to this work, he criticizes al-Sanhūrī, without mentioning him by name, for placing Sharía after both legislation and custom (Husayn 2001, 1:54).

15 In his survey of the modern codification movement in the Arab world, al-Sanhūrī distinguished three models: countries that did not develop codes (e.g., Saudi Arabia and 
These IIFA deliberations on the role of custom in Islamic law can, therefore, reflect the extent to which a gap continue to exist between the supporters of a Shari $a$-based legal framework on the one hand and the supporters of modern positive or secular law on the other. While the former would assert that Sharía is capable of accommodating modern challenges, as it did in the pre-modern period, the latter could argue that modern realities present far greater challenges and, therefore, require radical changes in the form and substance of all pre-modern legal systems (Abū Țālib 2006, 271). This, however, does not suggest that the dichotomy between Islamic and secular legislation is usually perceived as absolute or impermeable. For example, some researchers underscore the prominent role that Islamic law has played in shaping legal codes since their introduction, particularly in the area of family law. From this perspective, legal codes are meant mainly to reorganize classical legal rules rather than replace them. Codification is, therefore, seen as an important method of reform and renewal that aims to allow Sharía to keep up with modern developments ('Umar 2017, 643). The fact that several scholars have undertaken efforts to prove the feasibility of shaping Islamic rules in codified form further supports this point. This latter perspective seems to question the argument that Sharí $a$ cannot be reinstated in the wake of the modern legal reform movement, which ended up, with few exceptions, replacing the Sharĩa system with modern secular codes along European models. According to this argument, the ensuing changes amounted to nothing less than the demise of Sharía (Hallaq 2004, 24; Hallaq 2013).

As the IIFA deliberations illustrate, the negative perception of legal codes in the Muslim world is not only due to their impact on limiting the role of Sharía and even causing its decline in the realm of official legislation but perhaps equally due to their association with foreign occupation. The prominent role that custom assumed in these codes is perceived to have been achieved at the expense of Sharīa. For example, the Egyptian legal scholar Muhammad Jabr al-Alfi points out the role of Western occupation throughout the Muslim world (e.g., in North Africa, the sub Indian continent, and Indonesia) during the 19th and early 2oth centuries in emphasizing the significance of local customs and incorporating them in the newly developed legal codes (al-Alfi 1988, 3290-4). Similarly, the late Jordanian scholar 'Umar Sulaymān al-Ashqar (d. 2012) underscored the competition between Sharía and positive legislation in the modern period. He described the unseating of Sharîa and its replacement by

Yemen); countries that relied on the Ottoman Majalla (e.g., Syria, Palestine, Jordan, Iraq, and Libya); and countries that followed the French example (e.g., Egypt, Lebanon, Tunisia, Algeria, and Morocco) (al-Sanhūrī 2006, 2:538). 
secular laws as an unwarranted and blameworthy act that was facilitated by the political power-wielders (jināyat al-mutanaffidhin) (al-Ashqar 1988, 3212).16 Ultimately, this modern juristic discussion on the role and function of custom under Sharĩa provides important insights into how Muslim jurists strive to situate Shari $a$ in the modern period and the extent to which they envision ways to revitalize its role in the future. Given the historical role it played in the development of Islamic law and legal theory, custom is identified as an important tool to achieve these objectives in an organic and authentic manner.

\section{Nature and Scope of Sharīa}

The second main point that the IIFA proceedings highlight has to do with the role of custom in defining the nature and also the scope of Sharia $a$. In this connection, custom is often invoked to support several faith-based assumptions pertaining to Sharīa's comprehensive scope, universal appeal, and eternal validity. ${ }^{17}$ In general, participants in this discussion sought to emphasize the important role that custom played not only in the historical development of Islamic law in different social and cultural settings, but also in ensuring the ongoing adaptability and functionality of Sharīa.

\section{Custom, Change and Ijtihād}

Several contributors pointed out the frequent remarks made by jurists in different generations against what was deemed rigid implementation of Shari $a$ and lack of attention to the changing circumstances that necessitate adjustment and amendment of certain legal rules (al-Ashqar 1988, 3211; Doukoure 1988, 3418). In response, they suggested that modern juristic treatment of custom should move beyond mere repetition of classical discussions and should instead aim to reinvigorate the Sharita system by revisiting pre-modern custombased rules. ${ }^{18}$ This approach should reveal the potential of Sharīa to meet

16 In one of his fatwas on the religious status of a judge who passes judgments that may conflict with Sharīa on the basis of secular law, the former rector of al-Azhar Mahmūd Shaltūt (d. 1963) notes that the blame for such state of affairs should not be placed on judges only but rather on the rulers who created this judicial structure, on the legislators who developed these secular laws, and on litigants who resort to these courts (Shaltūt 2009, 38-40; Brown 2011, 460).

17 For more on the debate on the scope of Sharīa between comprehensiveness and minimalism, see Brown 2011, and Jackson 2017.

18 This is particularly evident when a scriptural proof itself is based on a contemporary custom as is the case with the famous report on the usurious items and whether they should be measured by weight or by volume. As Ibn 'Ābidīn (d. 1252/1836) notes, within 
modern challenges and to regain its deserved status as the main legal system in the Muslim world (al-Ashqar 1988, 3229; Ju'ayyit 1988, 2985-6).

Revisiting legal rules, especially ones that are grounded in custom, has been a recurring theme in the Islamic legal tradition, particularly in the domain of legal application as is the case in the fatwa literature and other related genres. The domain of legal application is closely related to juristic discussions on ijtihād as the process that governs and regulates both legal derivation and application. Several contributions highlighted the role of custom in different aspects of $i j t i h \bar{a} d$-related discussions and how it interacts with other legal sources and principles, which include: determining the interpretation of certain terms through common linguistic expressions; serving as a facilitating or competing factor for analogical reasoning; and more broadly, being a means for the achievement of public interest istișlăh. With regard to the use of custom for the interpretation of terms, the jurists are unanimous that linguistic customs ('urf qaw $\bar{l}$ ) can be used for the specification of general terms, as mentioned above in the example of the names of currencies such as dirham. The role of practical customs in specifying general rules, however, has been subject to disagreement. While the majority of the Hanafìs and Mālikīs allow specification on the basis of practical customs, the Shāfi'is do not. ${ }^{19}$ In the case of analogical reasoning, the most common use of custom, particularly within the Hanafi school is in the case of hidden or subtle qiyās, which is also referred to as istihsān or juristic preference. In this case custom serves as the main factor behind super-

the Hanafĩ school, the majority opinion is that these items should be measured forever according to what is indicated in the report. Abū Yūsuf (d. 181/798), however, argued that if such a custom governing these units of measurement were to change, related rules should change as well (Ibn 'Ābidīn n.d., 2:116). The Mālikī jurist Shihāb al-Dīn al-Qarāfī (d. 684/1285) notes that custom-based rules should change if the underlying customs were to change. He also advises fellow jurists not to follow blindly what is written in the works of earlier jurists without giving careful thought to the changing circumstances (alQarāfì 2001, 1:314).

19 Some exceptions, however, exist as is the case with al-Qarāfĩ from the Mālikīs and alZayla'i (d. 743/1342) from the Hanafîs who do not support specification on the basis of practical customs (al-Qarāfĩ 2001, 310; Dönmez 1988, 3316). Another related point is the distinction between specification and qualification (taqyūd). In the case of qualification, both types of custom can qualify absolute terms. Examples include the term hajj, which literally means seeking to visit a dignified place but the customary meaning stands for the Islamic form of pilgrimage. Similarly, the Prophetic report indicating units of measurement is interpreted to mean the commonly used units. Also if a specific type of meat is common in one region (e.g., lamb), it is taken to signify what is intended by the term "meat" unless otherwise explicitly indicated. The Hanafì argument on the validity of specification by the practical custom is compared to the validity of qualification by the practical custom as well (Abū Sunna 2004, 164-7, 219-20). 
seding a straightforward qiyās in order to accommodate a common practice. One of the famous examples is the contract of lease, which is meant to facilitate the exchange of benefits but it goes against the general ban on the sale of non-existing items. It was however allowed on the basis of common custom, which was also the case with istișn $\bar{a}^{c}$. On the other hand, custom also works within analogical reasoning by ensuring the most appropriate implementation of rules through the process of tahqüq al-manāt. Finally, keeping in mind the juristic discussion on the finiteness of scriptural proofs and infiniteness of real-life incidents, the use of custom for the incorporation of common practices that are deemed of public benefit remains one of the important ways through which Sharīa can keep up with the emerging social needs, as long as such practices do not conflict with the fundamental principles of Sharita (Dönmez 1988, 3315-23).

The main limitation to these remarks on the role of custom in accommodating social change and also in the ongoing process of $i j t i h \bar{a} d$ is that they remain mostly at the level of theoretical juristic abstraction. Some participants pointed out the need to bring these ideas as close as possible to the real world. For example, modern applications of custom should take into consideration the radical changes that have shaped the world in the past few decades in all walks of life, particularly in economic activities and commercial transactions. (Majallat 1988, 3455; 3459).

\section{Implementation of Sharîa $a$ in the Modern Period}

This discussion on the role and function of custom under Sharita relates closely to another topic that was also discussed in the same session of the IIFA, which is the implementation of Sharita in the modern period. ${ }^{20}$ Muslim jurists and religious scholars often note that the introduction of Western-inspired legal codes has detracted from the role and status of Sharīa (Mahmūd n.d., 1:357-8; $2: 428 ; 2: 448)$. For them these codes have served as an important step in the

20 Submissions to this session included a paper by the late prominent Tunisian scholar Muhammad al-Habīb ibn al-Khūja (then serving as the chairman of IIFA), a shorter paper by the Saudi scholar 'Abd al-Wahhāb Ibrāhīm Abū Sulaymān, and a transcript of a Friday sermon on the topic by the Imām of the Holy Mosque in Mecca, Șālih ibn Ḥumayd. Some of the main points that were highlighted in these submissions include: competition between Sharīa and positive law; emphasis on the far-reaching scope of Sharía, which is not limited to the private affairs of individual Muslims; refuting the criticism levelled against Shari $a$ and its compatibility in the modern period; and addressing obstacles barring the implementation of Islamic law. 
process of installing secular political-legal systems. This section of the proceedings on this topic, therefore, dovetails with the other section on custom. In general contributions on this topic aimed to address the critique made by the supporters of positive legal codes against Sharîa, mainly its depiction as an archaic system that does not suit modern needs and realities. This critique, which can also be traced to public controversies surrounding the development of legal codes in the emerging Muslim-majority nation states, emphasizes the inadequacy of Sharía in its pre-modern form and the extent to which it exhausted its potentials on the eve of the legal reform movement. For example, some of the main critical remarks that one of the scholars of al-Azhar addressed in response to the new civil code of 1949 include: lack of a wellorganized and functioning legal structure to meet the needs of a modern justice system: overwhelming diversity within the Islamic legal tradition, which makes it difficult for judges to access or derive pertinent legal rules easily and effectively; and entailment, within the Shari $a$ system, of certain rules that are deemed by modern civilization as harsh and inhumane (Husayn 2001, 1:44). To rebut these arguments, he emphasized the universal as well as eternal validity of the fundamental principles of Sharía. Accordingly, defects within the justice system prior to the introduction of the legal codes cannot be attributed to Sharía itself but should rather be attributed to political systems for failing to implement Sharīa efficiently and effectively. The diversity of legal opinions within the Islamic legal tradition can be an advantage rather than a disadvantage and these opinions reveal the resourcefulness of the tradition, which can also inspire more creative solutions for unprecedented cases. Moreover, the inability of judges to deal with the classical works of Islamic law has to do with modern legal education and training, which does not equip graduates with the necessary skills to understand let alone engage with the Islamic legal heritage. Ultimately, the introduction of modern legal education has created a gulf between the scholars of Sharita and positive law experts. ${ }^{21}$ Finally, with regard to

21 Wael Hallaq has written extensively on the impact of modern legal reform on the Sharîa system and on traditional scholars. For example, he notes: "the transposition of the command of the law from the hands of the faqihs (the traditional legal professionals) to those of the state represents the most important phenomenon of modem legal reform, one that signified simultaneously the eternal loss of epistemic authority and the dawning of the much-abhorred authority of the state" (Hallaq 2003, 258). Elsewhere he also discusses the attitude of modern judges towards classical works of Islamic law. For example, speaking about modern judges in Egypt, including those serving on the Supreme Constitutional Court (scC), he notes "The secular training of the national-court judges equipped them, even with the best of intentions, to extract nothing more than the most general of principles. Their well-nigh ignorance of figh, of Quranic exegesis, of hadith (which the SCC largely ignored as a valid legal source), and even of basic skills in classical legal Arabic, 
the branding of certain Sharīa rules, particularly in the area of criminal law, as inhumane and incompatible with modern civilization, jurists often point out the revelatory origin of these rules and also the procedural constraints that are meant to ensure proper and equitable application of these rules (Husayn 2001, $1: 44-9) .^{22}$

To begin with, contributions to the IIFA discussion on the implementation of Sharita underscored the negative impact that positive legal systems have had on the status of Sharita. The development of legal codes is described as one of the most lasting blows of Western occupation, which continued even after the end of direct military colonization (Abū Sulaymān 1988, 3473). The development of the legal codes in the Muslim world is often traced to the increasing influence of European powers over the Ottoman Empire in the form of capitulations, which triggered a series of legal reforms (tanzimāt) that involved significant concessions in favor of these European powers and their citizens within Ottoman territories. Following the fall of the Ottoman Empire after the First World War and the emergence of nation states in the various Ottoman regions, legal codes became an integral part of the process of nation building (Ibn al-Khūja 1988, 3482). As noted above, the association between

largely barred them from any genuine understanding of what Sharīa's figh signified or even technically meant. It is common knowledge—-for anyone familiar with the modern Arab legal profession - that this profession as a rule considers the figh to be culturally remote, juristically complex and a judicially obscure system of rules, and for those members who have little sympathy for the Islamists, figh is downright primeval, ultraconservative and anti-modern" (Hallaq 2009, 481).

22 On the procedural constraints within the Sharîa system in the pre-modern period, see (Rabb 2015). In addition to the critical remarks on the limitations of a Sharīa-based system mentioned above, contributors also pointed out several other points that were used to justify the replacement of Sharía by positive laws. They include, for example, the inability to cope with and address emerging needs due to the closure of the gate of ijtihad for centuries. By contrast, legal codes can be easily updated and amended if need be. Sharîa is also described as a highly idealistic system that is mainly concerned with moral issues and that is the reason why it grew out of touch with the passage of time. Finally, the Sharīa system along with its legal heritage were not entirely original but they were largely borrowed from other foreign sources, either from earlier scriptures or from the existing legal systems in the conquered regions. In response to these remarks, contributors emphasized the potency of the Sharía system, which remained the main legal framework for Muslims up until the modern period before being ousted mainly with the help of foreign forces during the colonization period (Ibn al-Khūja 1988, 3484-7). These points seem to echo some of the main questions that have occupied modern scholarship on Islamic law. For example, one of these questions had to do with the nature of Islamic law in terms of its flexibility and ability to accommodate change over time. Another question had to do with the origins of Islamic law and the extent to which it had borrowed from other legal systems (Shabana 2010, 17-42). 
legal codes and foreign occupation has consecrated their image as a substitute and alternative to Sharīa.

The argument for the implementation of Shari $a$ takes for granted the internal, personal, private, and individual elements that pertain to the devotional and also ritualistic dimensions of Islamic law. The call for the implementation of Sharía, however, usually aims to emphasize the public, collective, and communal dimensions of Sharita that require the involvement of the state and the various branches of the government (executive, legislative, and judicial). Authors therefore often begin by emphasizing the comprehensiveness of Sharia and how it includes aspects that relate to the various aspects of a believer's life, both at the individual and collective levels (Ibn Ḥumayd 1988, 3514). This discussion, therefore, automatically raises the question of secularism and the extent to which it clashes with a Sharía-based system. This was already reflected in the paper of the late Tunisian jurist Ibn al-Khūja, which features this confrontation (al-muwājaha) between Sharîa and secularism in its title. In this paper Ibn al-Khūja surveys some of the works by the proponents of secularism in the Muslim world and reiterates the usual critique of secularism by both the religious scholars and Islamists. This critique emphasizes the historical roots of secularism in the West during the process of liberation from the authority of the Catholic Church. Moreover, the top-down imposition of secularism in the Muslim world, as was the case in Turkey, confirmed its perception as an unnecessary foreign solution that is often advocated by Westernized elites while lacking popular support (Ibn al-Khūja 1988, 3483-4, 3493).

Given the importance of the implementation of Shari $a$ as an aspirational goal for the global Muslim community (umma), contributors noted that it should be tied to actual and practical action plans. ${ }^{23}$ The participating scholars highlighted the significance of this issue by noting that it should be a top priority for the IIFA. It is closely linked to the mission of the institution and it can be considered one of the main reasons behind its establishment. The collective discussion, following presentation of the submitted papers, revealed how

23 For example, Abū Sulaymān suggested that work on this goal should be at three main levels. The first focuses on reforming religious education and its institutions to ensure that students are able to address real problems beyond rhetorical generalizations. The second focuses on the need to examine the legal heritage with a view to facilitate access to relevant information by developing, if necessary, carefully structured rules similar to the positive legal codes but also by producing critical editions of important works along with detailed indexes. This suggestion shows that not all Muslim scholars are opposed to codification in principle and that it can be used as a means to modernize Islamic law. The third focuses on developing a plan for tackling important research questions in the area of Sharīa $a$ studies, particularly ones that relate to its implementation (Abū Sulaymān 1988, 3475-6). 
much this was already a hot-button issue in many countries, particularly ones that had undergone or were undergoing Islamization programs such as Sudan and Pakistan. Other countries were also developing or working on comprehensive or specific Islamic codes such as Egypt, Libya, and Kuwait. In light of these practical experiences, some participants pointed out the need for further research on specific issues. For example, in Sudan there was a problem concerning the applicability of Sharîa rules on non-Muslims. In Pakistan, there were problems concerning legal diversity and the necessity of adherence to one single school. ${ }^{24}$ Some participants took part in actual programs in their countries and pointed out some of the problems that faced these efforts. For example, the Libyan legal expert Ibrāhīm al-Ghuwayyil, who served on a high commission for the codification of Sharita, noted that they faced challenges concerning hudūd in the area of criminal law. Similarly in the area of civil and commercial law they faced problems concerning the issue of usury. These problems had to do with existing relationships with the international economic system. He therefore emphasized the need to pursue these programs in a gradual and incremental manner (al-Ghuwayyil 1988, 3532). ${ }^{25}$ The prominent scholar Yūsuf al-Qaraḍāwī supported the idea of gradual and incremental implementation but he cautioned that this approach is often used to buy time. He noted that it would be important to develop an action plan indicating tangible steps and objectives (Majallat 1988, 3541).

Others insisted that the role of the IIFA in this regard, since its members officially represent their countries, is to urge governments to start the process of implementation. For example, the Saudi scholar Ahmad Muhammad Jamāl argued that implementation has to start top down rather than bottom up. This is perceived to be much more effective than engaging in long-term programs of education and awareness raising (Jamāl 1988, 3526). In response,

24 On the question of religious minorities in Pakistan see Zaman 2018, 164-94. Researchers point out several additional issues, particularly the Hudood Ordinances, in their evaluation of the Islamization program in Pakistan under General Zia-ul-Haq, see Zaman 2018, 87,105 , passim. It is interesting to note that no specific reference was made to Zia-ul-Haq, who died in August 1988, a few months prior to this IIFA meeting, which was held in December 1988. I am grateful to one of the anonymous reviewers for alerting me to these points about the Islamization program in Pakistan during the reign of Zia-ul-Haq (19771988). Similarly, no further details were discussed concerning the Islamization program in Sudan under the military rule of Jafar al-Numayrī (1983-1985), which had also been extremely controversial.

25 Apart from these cursory references to the different Islamization programs in countries such as Sudan and Pakistan, the discussions did not deal with any of them in any substantive way. They included, however, several references to the various legislative initiatives in several Muslim-majority countries to codify Sharîa rules in the different legal branches. 
Ibn al-Khūja noted that it would be important to create the proper culture that would make the implementation of Shari ${ }^{-} a$ possible. He pointed out the fact that in most Muslim-majority countries constitutions already list Islam as the official religion and Sharí $a$ at least as a source of legislation but in reality these references are not reflected in actual laws and policies. Therefore, only through education and literacy programs, people can translate these nominal references to Islam and Sharīa into reality (Ibn al-Khūja 1988, 3528). The late Syrian scholar Wahba al-Zuhayli emphasized the importance of creating an effective Islamic alternative to positive codes even if by creating similar Shari $a$ based codes. He remarked that when rulers are asked to implement Sharîa, they ask about an effective Sharīa-based alternative (Majallat 1988, 3530-1). In response, the Egyptian legal expert Muștafā al-'Arjāwī noted that detailed Islamic codes have already been developed in countries such as Egypt and have been waiting indefinitely for approval from the parliament (al-'Arajāwī 1988, 3539). ${ }^{26} \mathrm{He}$ attributed this reluctance to the lack of political will. ${ }^{27}$ In light of these remarks several participants felt that the topic required further planning and preparation. Some even suggested that it should be an ongoing topic of discussion and a permanent item on the agenda of IIFA meetings. ${ }^{28}$

This discussion on the implementation of Sharīa ties well with the earlier discussion on custom. For example, the discussion on custom shows the extent to which the participants strove to mine the Islamic legal heritage with the

26 Former speaker of the Egyptian parliament Șufì Ḥasan Abū Ṭālib noted that a series of codes were submitted to the legislative committee in the parliament in 1982. These codes were developed in consultation with Sharía scholars from al-Azhar and other Egyptian universities (Abū Țālib 2006, 271).

27 Some scholars noted that Islamic alternatives can easily be developed. For example, this can be achieved in the area of transactions by revisiting usury-related articles. Others, however, questioned this piecemeal method of reform. For example, al-Qaraḍāwī pointed out that reconciliation between Sharía and positive codes by removing or amending certain items would not be sufficient because the process of codification has to be rooted in a particular philosophy and methodology in order to ensure the consistency and coherence of all articles (Majallat 1988, 3541).

28 The resolution that was passed concerning this topic reiterated the need to pursue this issue and to coordinate the efforts of researchers and institutions in this regard, while studying and utilizing previous achievements in order to avoid duplicating them. The topic was also highlighted in several subsequent resolutions including: a resolution concerning the issue of intellectual invasion (al-ghazw al-fikrī), underscoring the need for the implementation of Sharīa, during the 7 th session that was held in Jeddah in May 1992; a resolution concerning Islamic unity during the 11th session that was held in Bahrain in November 1998; a resolution concerning the Islamic civilizational vision during the 18th session that was held in Malaysia in July 2007; and a resolution on the implementation of Sharita and the status of non-Muslims during the 22nd session that was held in Kuwait in March 2015. 
goal of identifying possible resources to enhance the capacity of Shari $a$ and facilitate its implementation in the modern period. As much as implementation of Sharîa would require mastery of Islamic rules and regulations, it would also require understanding of how such rules and regulations can be adjusted to different real-life incidents. Therefore, calls or demands for the implementation of Sharîa would necessitate ongoing assessment of relevant customs in light of the ever changing circumstances. Incidentally, one salient point that was emphasized in both discussions was the need to bridge the gap between theoretical juristic abstractions and actual conditions in the real world, particularly in light of the impact of modern technology and means of tele-communication, which have fundamentally transformed people's understanding of reality $\left(a l-w \bar{a} q i^{i}\right)$ and how people interact with each other. Therefore, as several contributors noted, the main task at hand of modern jurists is to examine the Islamic legal corpus carefully with the aim not only to revisit archaic custombased legal rules but also to accommodate new and emerging customs, which in essence represent actual collective needs that require regulation (Majallat $1988,3455 ; 3459)$. The fact that custom has consistently been invoked in subsequent IIFA meetings in connection with several topics indicates its perception as an important means to demonstrate the flexibility of Shari $a$ and its capacity to accommodate newly emerging issues. ${ }^{29}$

Similarly, as was the case with the discussion on custom, the discussion on the implementation of Sharîa reflects the participants' view of Sharîa and the extent to which they envision a greater role for it in the future. Both discussions, however, reveal a growing realization that the future of Sharita is

29 For example, it was highlighted in: a resolution concerning royalties and determination of intellectual rights during the same $\left(5^{\text {th }}\right)$ session; a resolution concerning the conclusion of contracts by modern means of communication and another on modern forms of payment, during the 6th session that was held in Saudi-Arabia in March 1990; a resolution concerning confidentiality in the medical professions, during the 8th session that was held in Brunei in June 1993; a resolution concerning novel issues (nawazil) emphasizing the need to give consideration to the changing customs and circumstances during the 11th session that was held in Bahrain in November 1998; a resolution concerning investment of religious endowments during the 15th session that was held in Oman in March 2004; a resolution concerning disagreements between the husband and his working wife during the 16th session that was held in the United Arab Emirates in April 2005; a resolution concerning the etiquettes of fatwa-issuing and another on the value of promises in financial transactions during the 17 th session that was held in Jordan in June 2006; a resolution concerning amenities and ancillary rights during the 18th session that was held in Malaysia in 2007; a resolution concerning the responsibility of banks for risks emanating from mismanagement of funds during the 22nd session that was held in Kuwait in March 2015; a resolution concerning insolvency and bankruptcy during the 23rd session that was held in Saudi-Arabia in November 2018. 
entwined with the nation state and its codified law. ${ }^{30}$ These two discussions, in turn, relate to other larger questions such as those on Islam and politics and secularity. ${ }^{31}$ While this paper cannot deal with these questions in detail, the proceedings examined here should be placed within the evolving debates surrounding these questions, which remain for the most part open. In particular, it would be important to investigate the role of these contributions as part of a transnational normative discourse that developed in parallel to similar discourses at the national level within the boundaries of individual nation states. It would also be important to evaluate the extent to which this transnational normative discourse as well as similar subsequent ones have been responsive to relevant social and political developments such as legislative initiatives, Islamization programs, or constitutional reforms.

\section{Concluding Remarks}

The foregoing discussion shows how Muslim scholars in the modern period appeal to custom not only to emphasize the potency of Sharîa but also to defend it against the encroaching influence of positive legislation. The inclusion of custom in several civil codes as an independent legal source, even before Shari ${ }^{-} a$, provoked a heated debate between the 'ulam $\bar{a}$ ' and positive law scholars. This debate between the ' Ulam $\bar{a}$ ' and positive legal experts reveals two distinct conceptualizations of the place of custom within the legal system. From a secular legal perspective, on the one hand, custom embodies deeply-rooted norms, values, and traditions. Moreover, the distinction between 'áda and 'urf

3o The second discussion revealed a degree of ambiguity surrounding the term "implementation of Sharīa" itself. While some participants took it to mean rendering Sharīa in a codified form to facilitate integration within the existing body of codified laws, others took it to mean making efforts to enact Sharīa rules and regulations in more general terms, particularly by exhorting political leaders to take practical measures towards this goal (Majallat 1988, 3526).

31 Recent studies have observed that the role that Shari $a$ is allowed to play in the public sphere, particularly in relationship to positive law, is subject to the place that the dominant secular order would be willing to concede. Moreover, the scope of Sharîa deemed to be applicable publicly through incorporation into legislation is determined by the state's exercise of its sovereign power (Agrama 2012, 1-41; Hallaq 2018, 132). From another perspective, Sherman Jackson draws a distinction between the secular and what he refers to as the Islamic secular. He argues that the latter stands for the domain that does not squarely fall under the realm of Sharía rule. Knowledge and assessment of prevailing customs would play an important role in delineating the boundaries of this domain (Jackson 2017). 
draws the boundaries between a normative custom and a non-normative one. The acknowledgement of a custom as normative relies on its popular recognition and long-term establishment. Muslim scholars, on the other hand, while recognizing both the legal value of custom and also the historical role it has played in the Islamic legal heritage, insist that it can only be a secondary or subsidiary source. The qualification of custom as a secondary or subsidiary source is predicated on the underlying epistemological structure of Islamic law, which recognizes the primacy of revelatory sources. ${ }^{32}$ The discussion on the implementation of Sharita in the modern period can be seen as an extension to the first discussion on custom, and indeed several scholars participated in both discussions. While the first aims to point out the potentials of Sharía and the rich resources of the Islamic legal tradition, the second aims to emphasize the need, from the perspective of the 'ulama $\bar{a}^{3}$, to fix the mistake that was made against Shari $a$ when it was sidelined and substituted by positive legislation.

Both discussions reveal the mixed feelings that many Muslim scholars have towards secular legislation. These mixed feelings range from a sense of injustice, disempowerment, alienation, estrangement, and betrayal, on the one hand, to a sense of responsibility, commitment, and dedication to the goal of revitalizing and restoring the Sharīa-based legal system, on the other. The contributions also reveal that these mixed feelings on the part of Muslim scholars and jurists come as a reaction to what is perceived to be an organized campaign by the advocates of secular legislation who criticize suggestions to give precedence to Sharîa over 'urf. Both of these discussions, therefore, are indicative of the polarized legal landscape in many Muslim-majority countries. More particularly, they demonstrate how the emergence of positive law scholars and experts in the post legal reform era constituted a formidable challenge to the role and authority that the scholars of Sharí' a, the 'ulamas', used to have in the pre-modern period.

32 The resolution that was passed during this session concerning 'urf comprised four main points: its definition, scope, conditions, and significance. According to the definition indicated, 'urf stands for what people adopt by way of habit, which may include words, actions, or even inaction and it may or may not align with Sharía. The scope of 'urf may be specific or general and each of these two types operates within its respective domain. The conditions of a valid 'urf are: it should not be in conflict with Shari'a; it should be recurrent and dominant; it should be in existence at the time of the transaction; and it should not go against an explicit contractual stipulation. Finally, the resolution urges jurists, particularly in their capacity as judges or muftis, to pay attention to the changing customs and not to adhere blindly to the opinions of preceding jurists. 
Finally, one may wonder whether or to what extent these discussions that took place in 1988 are still relevant today in 2019. After more than three decades this question is definitely justified. Indeed a lot has happened but for historical reasons, these discussions show the attitude of Muslim scholars on the place of Sharía in the modern period, particularly in light of the perceived threat that positive law has constituted. The IIFA proceedings show that the issue of custom acquires added importance because it served as the locus of the disagreement between the 'ulama $\bar{a}$ ' and positive law scholars. While premodern juristic discussion on custom concentrate on the role, function, and limitations of custom within the dominant Sharîa framework, most modern juristic discussions include a comparative perspective to distinguish custom under Sharîa from its place in positive law and jurisprudence. As several social and political developments over the past few decades have shown, these questions on the relationship between custom and Shari $a$, the place of Sharia in the public sphere, and implementation of Sharīa have not disappeared simply because they have become questions of identity. For example, as the recent events of the Arab Spring indicate, soon after the success of the first wave of popular uprisings resulting in the toppling of established secular regimes, these questions have become main items for public debate. The discussions that this paper examined, therefore, serve as an important link between earlier discussions coinciding with the development of civil codes (late 19th-mid2oth century) and more recent events such as those associated with the Arab Spring in the early 21st century.

\section{Bibliography}

Abou El Fadl, Khaled. 2001. Speaking in God's Name: Islamic Law, Authority and Women. Oxford: Oneworld.

Abū Sulaymān, 'Abd al-Wahhāb Ibrāhīm. 1988. "Tațbīq al-Sharīa al-Islāmiyya." Majallat Majma' al-Fiqh al-Islāmī 5(4):3473-7.

Abū Sunna, Aḥmad Fahmī. 2004. al-'Urf wa-al-āada fì Rảy al-Fuqahā': 'Arḍ Nazariyya fì al-Tashrī al-Islāmī. Cairo: Dār al-Bașāir.

Abū Ṭālib, Șūfì Ḥasan. 2006. Taṭbìq al-Sharīa al-Islāmiyya fì al-Bilād al-'Arabiyya. Cairo: Dār al-Nahḍa al-'Arabiyya.

Agrama, Hussein Ali. 2012. Questioning Secularism: Islam, Sovereignty, and the Rule of Law in Modern Egypt. Chicago: The University of Chicago Press. al-Alfi, Muhammad Jabr. 1988. "al-'Urf: Bahth Fiqhī Muqāran." Majallat Majmac al-Fiqh al-Islämī 5(4):3261-3295. 
al-Ashqar, 'Umar Sulaymān. 1988. "al-'Urf bayn al-Fiqh wa-al-Qānūn.” Majallat Majma` al-Fiqh al-Islāmī 5(4):3211-3257.

al-Ashqar, 'Umar Sulaymān. 2012. al-Sharīa al-Ilāhiyya. Amman: Dār al-Nafāis lil-Nashr wa-al-Tawzī‘ .

al-Dabw, Ibrāhīm Fāḍil. 1988. "Naẓariyyat al-'Urf fī al-Fiqh al-Islāmī." Majallat Majmac al-Fiqh al-Islāmī 5(4):3183-3200.

al-Jīdī, 'Umar 'Abd al-Karīm. 1982. al-'Urf wa-al-'Amal fì al-Madhhab al-Mālikī wa-Mafhūmuhumā ladā 'Ulamā’ al-Maghrib. Rabat: Maṭba'at Faḍāla.

al-Khayyāt, 'Abd al-'Azīz. 1977. Nazariyyat al- Urf. Amman: Maktabat al-Aqșā.

al-Mays, Khalīl Muḥȳi al-Dīn. 1988. "al-'Urf." Majallat Majma‘ al-Fiqh al-Istāmī 5(4):2927-2971.

al-Minyāwī, Makhlūf ibn Muḥammad al-Badawī. 2010. Al-Muqāranāt al-Tashrīyya: Tațbìq al-Qānūn al-Madan̄ wa-al-Jinā̄ì 'alā Madhhab al-Imām Mālik, edited by Muḥammad Aḥmad Sarrāj and 'Alī Jum‘a Muḥammad, 2 vols. Cairo: Dār al-Salām. al-Qarāfî, Shihāb al-Dīn Aḥmad ibn Idrīs. 2001. Kitāb al-Furūq: Anwār al-Burūq fì Anwā̄ al-Furūq, edited by Muḥammad Aḥmad Sarrāj and 'Alī Jum'a Muḥammad, 4 vols. Cairo: Dār al-Salām.

al-Sanhūrī, 'Abd al-Razzāq Aḥmad. 20o6. "al-Qānūn al-Madanī al-'Arabī.” In Islāmiyyāt al-Sanhūrī Bāshā, edited by Muḥammad 'Imāra, 2 vols., 2:537-558. Mansoura: Dār al-Wafā’ lil-Tibā‘a wa-al-Nashr wa-al-Tawzī‘.

al-Sanhūrī, 'Abd al-Razzāq Aḥmad. 20o6. "Harakat al-Taqnīn al-Madanī fī al-'Ușūr al-Ḥadītha." In Islāmiyyāt al-Sanhūrī Bāshā, edited by Muhammad 'Imāra, 2 vols., 2:485-536. Mansoura: Dār al-Wafầ lil-Ṭibā'a wa-al-Nashr wa-al-Tawzī‘.

al-Suyūṭī, Jalāl al-Dīn 'Abd al-Raḥmān. 2004. al-Ashbāh wa-al-Nazāàir, edited by Muḥammad Muhammad Tāmir and Ḥāfiz 'Āshūr Ḥāiż. Cairo, Dār al-Salām.

al-Taftāzānī, Mas'ūd ibn 'Umar. 1998. Sharh al-Maqāṣid, edited by 'Abd al-Raḥmān 'Umayra, 5 vols. Beirut: 'Ālam al-Kutub.

Brown, Jonathan. 2011. "Is the Devil in the Details? Tensions Between Minimalism and Comprehensiveness in the Shariah." Journal of Religious Ethics 39(3):458-472.

Dönmez, İbrahim Kafi. 1988. "al-'Urf fī al-Fiqh al-Islāmī." Majallat Majma` al-Fiqh al-Islāmī 5(4):3299-3369.

Doukoure, Boubacar. 1988. "al-'Urf." Majallat Majma' al-Figh al-Islāmī 5(4):3411-3419.

Grote, Rainer and Tilmann J. Roder, eds. 2016. Constitutionalism, Human Rights, and Islam after the Arab Spring. Oxford: Oxford University Press.

Hallaq, Wael. 2003. "Juristic Authority vs. State Power: The Legal Crisis of Modern Islam." Journal of Law and Religion 19(2):243-258.

Hallaq, Wael. 2004. "Can the Shari'a be Restored?" In Islamic Law and the Challenge of Modernity, edited by Yvonne Yazbeck Haddad and Barbara Freyer Stowasser. Walnut Creek, CA: Altamira Press.

Hallaq, Wael. 2009. Sharīa: Theory, Practice, Transformations. Cambridge: Cambridge University Press. 
Hallaq, Wael. 2013. The Impossible State: Islam, Politics, and Modernity's Moral Predicament. New York: Columbia University Press.

Ḥaydar, 'Alī. 2010. Durar al-Ḥukkām, Sharh Majallat al-Aḥkām. Trans. Fahmī al-Ḥusaynī, 4 vols. Beirut: Dār al-Kutub al-'Ilmiyya.

Ḥusayn, Sayyid 'Abd Allāh 'Alī. 2001. al-Muqāranāt al-Tashrīiyya bayn al-Qawānīn al-Waḍiyya al-Madaniyya wa-al-Tashrī al-Islāmī: Muqārana bayn Fiqh al-Qānūn al-Faransī wa-Madhhab al-Imām Mālik ibn Anas Raḍiya Allāh 'Anh, edited by Muhāmmad Aḥmad Sarrāj, 'Alī Jum‘a Muḥammad, and Aḥmad Jābir Badrān, 4 vols. Cairo: Dār al-Salām lil-Ṭibā'a wa-al-Nashr wa-al-Tawzī‘ wa-al-Tarjama.

Ibn ‘Ābidīn, Muhammad Amīn. n.d. "Nashr al-'Arf fī Binā’ Bađọ al-Aḥkām 'alā al-'Urf." In Majmūat Rasā̉il Ibn 'Ābidīn, 2 parts in one volume, 2:112-145. Beirut: Dār Ihỵā' al-Turāth al-'Arabī.

Ibn al-Khūja, Muḥammad al-Ḥabīb. 1988. "al-Muwājaha bayna al-Sharīa wa-al'Almana." Majallat Majma'al-Figh al-Islāmī 5(4):3481-3507.

Ibn Fāris, Abū al-Ḥusayn Aḥmad. 1979. Mújam Maqāȳss al-Lugha, edited by 'Abd al-Salām Muhammad Hārūn, 6 vols. Beirut: Dār al-Fikr lil-Ṭibā‘a wa-al-Nashr wa-al-Tawzī'.

Ibn Ḥumayd, Șāliḥ. 1988. "Tațbīq al-Sharīa." Majallat Majma` al-Fiqh al-Islāmī $5(4): 3513-3516$.

Ibn Nujaym, Zayn al-Ā̉bidīn ibn Ibrāhīm. n.d. al-Ashbāh wa-al-Nazāàir, edited by 'Ādil Sa'd. Cairo: al-Maktaba al-Tawfĩqiyya.

Jackson, Sherman. 2015. "Islamic Law, Muslims and American Politics." Islamic Law and Society 22:253-291.

Jackson, Sherman. 2017. "The Islamic Secular." American Journal of Islamic Social Sciences 34(2):1-31.

Ju'ayyiț, Kamāl al-Dīn. 1988. "al-'Urf." Majallat Majma' al-Figh al-Islāmī 5/4:2975-3180.

Jurjānī, Abū al-Ḥasan 'Alī ibn Muhammad. 2009. al-Ta'rīfāt. Beirut: Dār al-Kutub al-'Ilmiyya.

Lombardi, Clark B. 2006. State Law as Islamic Law in Modern Egypt: The Incorporation of Sharîa into Egyptian Constitutional Law. Leiden: Brill.

Lombardi, Clark B. and Nathan Brown. 2006. "Do Constitutions Requiring Adherence to Sharīa Threaten Human Rights? How Egypt's Constitutional Court Reconciles Islamic Law with the Liberal Rule of Law." American University International Law Review 21(3):379-435.

Maḥmūd, 'Abd al-Ḥalīm. n.d. Fatāwā al-Imām 'Abd al-Halīm Maḥmūd, 2 vols. Cairo: Dār al-Ma'ārif.

Maḥmūd, 'Abd al-Ḥalīm. 2003. Mawqif al-Islām min al-Fann wa-al-'Ilm wa-al-Falsafa. Cairo: Dār al-Rashād.

Majma` al-Fiqh al-Islāmī. 1986. "al-Taqrīr al-Āmm wa-al-Qarārāt lil-Mu’tamar al-Ta’sīsī li-Majma al-Fiqh al-Islāmī.” Majallat Majma` al-Fiqh al-Islāmī 1:43-56. 
Perreau-Saussine, Amanda and James B. Murphy, eds. 2007. The Nature of Customary Law: Legal Historical and Philosophical Perspectives. Cambridge: Cambridge University Press.

Qadrī, Muḥammad. 2007. Al-Aḥkām al-Shar'iyya fì al-Aḥwāl al-Shakhșiyya 'alā Madhhab Abī Hanīfa al-Nu'mān, edited by Bassām 'Abd al-Wahhāb al-Jābī. Beirut: Dār Ibn Ḥazm lil-Ṭibāà wa-al-Nashr wa-al-Tawzīc .

Qadrī, Muḥammad. 2011. Murshid al-Hayrān ilā Márifat Aḥwāl al-Insān fì al-Mu'āmalāt al-Shar'iyya 'alā Madhhab al-Imām al-A'zam Abì Hanīfa al-Nu'mān, edited by Muḥammad Aḥmad Sarrāj and Aḥmad Jābir Badrān, 3 vols. Cairo: Dār al-Salām.

Rabb, Intisar. 2015. Doubt in Islamic Law: A History of Legal Maxims, Interpretation, and Islamic Criminal Law. Cambridge: Cambridge University Press.

Rị̣ā, Muḥammad Rashīd. n.d. Tafsīr al-Qur’ān al-Hakìm al-Musammā bi-Tafsìr al-Manār. Cairo: al-Maktaba al-Tawfiqiyya.

Rị̣ā, Muḥammad Rashīd. 2012. Tārīkh al-Ustādh al-Imām Muḥammad Abduh, 3 vols. Cairo: al-Hay’a al-Mișriyya al-'̄̄mma lil-Kitāb.

Salvatore, Armando. 2009. "Tradition and Modernity within Islamic Civilization and the West." In Islam and the Modernity: Key Issues and Debates, edited by Muhammad Khalid Masud, Armando Salvatore, and Martin van Bruinessen, 3-35. Edinburgh: Edinburgh University Press, 2009.

Sayyid Aḥmad, Muḥammad 'Ațā al-Sayyid. 1988. "al-'Urf." Majallat Majma' al-Figh al-Islāmī 5(4):3203-7.

Shabana, Ayman. 2010. Custom in Islamic Law and Legal Theory: The Development of the Concepts of 'Urf and 'Ādah in the Islamic Legal Tradition. New York: Palgrave.

Shabana, Ayman. 2018. "Custom in the Islamic Legal Tradition." In The Oxford Handbook of Islamic Law, edited by Anver Emon and Rumee Ahmad, 231-248. Oxford: Oxford University Press.

Shalakany, Amr. 2001. "Between Identity and Redistribution: Sanhuri, Genealogy and the Will to Islamise." Islamic Law and Society 8(2):201-244.

Shaltūt, Maḥmūd. 2009. Al-Fatāwā: Dirāsa li-Mushkilāt al-Muslim al-Mu'āṣir fì Hayātih al-Yawmiyya al-Āmma. Cairo: Dār al-Shurūq.

Shammām, Maḥmūd. 1988. "al-'Urf bayna al-Fiqh wa al-Tațbīq." Majallat Majmac al-Fiqh al-Istāmī 5(4):3373-3402.

Shihadeh, Ayman. 2006. The Teleological Ethics of Fakhr al-Dīn al-Rāzī. Leiden: Brill.

Skovgaard-Petersen, Jakob. 1997. Defining Islam for the Egyptian State: Muftis and Fatwas of the Dār al-Iftā. Leiden: Brill.

Taskhīrī, Muḥammad 'Alī. 1988. "al-'Urf wa-Dawruh fī 'Amaliyyat al-Istinbāt." Majallat Majma' al-Figh al-Islāmī 5(4):3405-3408.

'Umar, 'Alī. 2017. al-Tajriba al-Mișriyya fì Tațbīq al-Sharīa al-Islāmiyya. Cairo: Sharikat al-Wābil al-Ṣayyib lil-Intāj wa-al-Nashr wa-al-Tawzī‘. 
'Umar, Muḥammad 'Abduh. 1988. "Manzilat al-'Urf fī al-Tashrī‘ al-Islāmī.” Majallat Majma' al-Fiqh al-Islāmī 5(4):3423-3435.

Vasalou, Sophia. 2008. Moral Agents and Their Deserts: The Character of Mu'tazilite Ethics. Princeton: Princeton University Press.

Watson, Alan. 2001. Society and Legal Change, 2nd ed. Philadelphia: Temple University Press.

Wizārat al-'Adl. [1950?]. al-Qānūn al-Madanī: Majmū'at al-A'māl al-Taḥ̂ììyya, 7 vols. Cairo: Mațba'at Dār al-Kitāb al-'Arabī.

Zaman, Muhammad Qasim. 2018. Islam in Pakistan: A History. Princeton: Princeton University Press. 